\section{Pokyny autorům}

Redakce přijímá příspěvky v češtině nebo ve slovenštině nebo $\mathrm{v}$ angličtině, které odpovídají odbornému zaměření časopisu Cor et Vasa. Zaslaný článek musí být určen výhradně pro publikaci v Cor et Vasa a doplněn prohláše ním, že nebyl a nebude zadán $\mathrm{k}$ uveřejnění $\mathrm{v}$ jiném časopise. Na konci rukopisu uvedte celá jména, vědecké hodnost a tituly všech autorů a adresy jejich pracovišt; hlavní autor uvede navíc číslo telefonu, lépe i mobilního telefonu, faxu, e-mailovou adresu a rodné číslo.

Příspěvky jsou uveřejňovány v češtině nebo ve slovenštině (s českým nebo slovenským souhrnem a anglickým souhrnem), články v angličtině jsou vedle anglického souhrnu doplněny českým nebo slovenským souhrnem. Příspěvek bude otištěn $\mathrm{v}$ tom jazyce, ve kterém bude dodán. Za překlad souhrnu odpovídá nakladatelství.

Práce je po stránce obsahové a formální posuzována nejméně dvěma anonymními recenzenty a podle jejich posudku roz hodne redakční rada o přijetí či odmítnutí. O výsledku bude autor vyrozuměn. Na základě připomínek recenzentů může být práce vrácena autorům $\mathrm{k}$ doplnění, $\mathrm{k}$ drobným či větším úpravám či $\mathrm{k}$ přepracování. Redakce si vyhrazuje právo provádět drobné stylistické úpravy a zkrátit rukopis, uzná-li to za nutné (v př́ípadě zkrácení rukopisu bude vyžádán autorův souhlas). Nevyžádané rukopisy a přílohy se nevracejí.

\section{ZPRACOVÁNÍ RUKOPISU}

Rukopis zasílejte pokud možno e-mailem. Používejte velikost písma 12 bodů, řádkování 1,5 . Články do vědecké části časopisu posílejte vedoucímu redaktorovi prof. MUDr. Vladimíru Staňkovi, CSc. (vladimir.stanek@medicon.cz), články do Kardia redaktorce Jiřině Kadeřávkové (j.kaderavkova@medprogo.com).

Na 1. stranu článku uvedte jeho název, celá jména všech autorů včetně titulů a celých názvů pracovište, dále připoj te souhrn a klíčová slova. Stránky příspěvku očíslujte, obrázky posílejte ve zvláštním souboru (souborech), popisky k obrazovým materiálům uvedite na konec článku.

$\mathrm{V}$ př́ípadě, že posíláte soubor více obrázků (do 10 mega) lze ho poslat e-mailem, soubor nad 10 mega posílejte poštou na CD-ROM. Definitivní verzi článku (po vašich úpravách na základě recenzních posudků) po vyrozumění vedoucím redaktorem můžete poslat e-mailem přímo do redakce časopisu Cor et Vasa.

Přílohy připojte na konec rukopisu v pořadí podle odkazů v textu. Nadpis tabulky pište př́mo nad tabulku. Obrazová dokumentace by měla být v dokonalém provedení (nejlépe ve formátech jpg, eps nebo tiff, rozlišení 300 DPI, nebo jako kvalitní fotografie, př́ípadně diapozitivy). Grafy dodávejte $\mathrm{v}$ křivkách (cdr nebo ai).

V textu označte místo, kam má být příloha zařazena.

Každý obrázek ukládejte do samostatného souboru, jednotlivé soubory pojmenujte podle př́ijmení prvního autora a čísla, pod kterým je příslušná dokumentace uvedena $\mathrm{v}$ textu (např. NOVAK1.tiff). Nemáte-li dostatek zkušeností s předáváním obrazových souborů, vyžádejte si podrobnějšî informace $\mathrm{v}$ redakci.

Rukopis má odpovídat pokynům Uniform Requirements for Manuscript Submitted to Biomedical Journals, připraveným Mezinárodním výborem vydavatelů lékařských časopisů (International Committee of Medical Journal Editors), které byly uveřejněny v Ann Intern Med 1988;108:258-65 a Br Med J 1988;296:401-5 a přetištěny v českém překladu v Cor Vasa 1993;35(1):K 16

\section{RUKOPIS MÁ OBSAHOVAT TYTO NÁLEŽITOSTI}

1. Text článku

2. Souhrn s názvem práce by měl mít u pưvodních sdělení jednotnou úpravu, tj. měl by obsahovat: cíl, metodiku, výsledky, závěry; u přehledů, kasuistik a aktuálních sdělení bez strukturování; asi 3-6 klíčových slov

3. Zkrácený titulek (do 60 znaků)

4. Seznam literatury

5. Dokumentace (grafy, tabulky, obrázky, schémata) by měla být provedena tak, aby byla dobře použitelná pro tisk

6. Texty k dokumentaci

Původní sdělení má být členěno do následujících kapitol: Úvod, Materiál a metodika, Výsledky, Diskuse, Závěry. Zkracování slov, zejména v nadpisech, se nedoporučuje. Pokud se nějaký výraz v textu často opakuje a autor uzná za vhodné jej zkrátit, uvede zkratku v závorce po prvním použití.

Formální úprava citací se řídí normou obvyklou v odborných časopisech. Užívá se plné formy citací: př́íjmení a zkratky jmen všech autorů, plný název citované práce v jazyce originálu, rok vydání, ročník, stránky: u monografií místo vydání, nakladatel, rok vydání a počet stran. Iniciály prvních jmen a zkratky názvu časopisu se píší bez teček, za znaky oddělujícími rok, ročník a stránky se nedělá mezera.

\section{PŘÍKLADY}

\section{Článek v časopise}

Schwartz PJ, Priori SG, Vanoli E, Zaza A, Zuanetti G. Efficacy of diltiazem in two experimental feline models of sudden cardiac death. J Am Coll Cardiol 1986;8:661-8. (Je-li autorů více než šest, uvedite první tři a zkratku et al.)

\section{Monografie}

Eisen NH. Immunology: an introduction to molecular and cellular principles of the immune response. 5th ed. New York: Harper and Row, 1974:406.

\section{Kapitola z monografie}

Streeter DD Jr. Gross morphology and fiber geometry of the heart. In: Berne RM, Sperelakis N, eds. Handbook of Physiology. The Cardiovascular System. Washington, D. C.: American Physiology Society, 1979:61-112.

Redakce se obrací na všechny autory s přáním, aby posílali do Cor et Vasa kratší články diskusního charakteru, které budou zařazovány do rubriky Aktuální sdělení (Short Communication). Rozsah jednotlivých článků této rubriky by neměl přesahovat tři strany strojopisu; redakce je zařadí do tisku v co možná nejkratší době a nebudou procházet recenzním řízením. I ty však musí obsahovat souhrn a klíčová slova. Aktuální sdělení vyjadřují stanovisko autora, které se může lišit od názoru členů redakční rady a redakce.

Redakce se obrací na recenzenty článků do Cor Vasa s prosbou, aby v případě, že je při recenzování článku obsah textu zaujme a rádi by se $\mathrm{k}$ němu vyjádřili, napsali $\mathrm{k}$ němu svůj vlastní komentár. Ten zašlete, prosím, vedoucímu redaktorovi společně s lektorským posudkem, abychom mohli zajistit současné uveřejnění článku i komentáře. 


\section{Instructions to Authors}

The Editorial Office will consider contributions in Czech/Slovak or English conforming to the professional thrust of Cor et Vasa. The manuscript should only be intended for publication in Cor et Vasa, and should be accompanied by a statement saying it has not been, and will not be, submitted to another journal for publication. Please give your full names and titles of all authors and addresses of their affiliations; in addition, the first author is asked to give their phone (preferably also mobile phone) and fax numbers, e-mail address and birth identification number.

The contributions appear in Czech or Slovak (with a Czech/Slovak abstract and an English abstract; papers in English include abstracts in English plus their respective Czech/Slovak abstracts). The manuscript will appear in the language it has been submitted in, while it is the editorial office's responsibility to provide abstract translation.

Each article is to be reviewed, in terms of its content and form, by a minimum of two anonymous reviewers, and the editorial board will use the reviewers' assessment either to accept or reject the manuscript. The author will be duly informed about the outcome of the review process. Depending on the reviewers' comments, the manuscript may be returned to the author(s) to make some additions, or some minor or major modifications, or to reword the manuscript. It will be the editorial office's right to make minor stylistic modifications and to shorten the manuscript should it deem this necessary (in case the manuscript is to be abbreviated, the author's consent will be sought). Not invited manuscripts (with figures and additional material) will not be returned to the author(s).

\section{MANUSCRIPT PROCESSING}

Please send your manuscript preferably by e-mail. The manuscript should be submitted in 12-point font and typed 1.5-spaced throughout. Manuscripts to the scientific part of the journal should be submitted to Prof. Vladimir Stanek, PhD, Editor-in-Chief (vladimir.stanek@medicon.cz) while submissions to Kardio should be forwarded to Jirina Kaderavkova, the Editor (j.kaderavkova@medprogo.com).

The first page of the manuscript should include its title and the authors' full names, together with their affiliations as well as an abstract with key words. The manuscript should be paginated throughout. Figures should be submitted in a separate file(s), with legends to figures/tables provided at the end of the manuscript.

File(s) containing several figures (up to 10 mega) can be sen by e-mail while bigger file(s) should be submitted by mail on a CD-ROM. Please send your revised version of the manuscript (incorporating reviewers' comments and suggestions), once you have been advised by the Editor-in-Chief accordingly, by e-mail direct to the Editorial Office of Cor et Vasa.

Attachments should be provided at the end of the manuscript, arranged as they appear in the manuscript. Legends to tables should appear above the table. Figures should be flawless (preferably in jpg, eps, or tiff formats, resolution 300 DPI, or high-quality photographs or slides). Diagrams should be provided in curves (cdr or ai).

Please indicate where each attachment should be placed throughout the manuscript.

Each figure should be submitted as a separate file; the files should be identified using the first author's name and their respective numbers within the manuscript (e. g. JONES1.tiff). Authors not experienced with submitting these files should seek more detailed instructions in the Editorial Office.

The manuscript should conform to the Uniform Requirements for Manuscript Submitted to Biochemical Journals developed by the International Committee of Medical Journal Editors which appeared in Ann Intern Med 1988;108:258-65 and in Br Med J 1988;296:401-5.

\section{EACH MANUSCRIPT SHOULD BE ARRANGED AS FOLLOWS:}

1. Text.

2. An abstract with title of the paper (with Original Contribu tions) should have a uniform format, i. e., it should be structured into Aims, Methods, Results, and Conclusions, 3-6 key words; no structuring is needed with Review Articles, Case Reports and Short Communications.

3. Running footline ( 60 characters and spaces as a maximum). 4. A list of references.

5. Additional material (diagrams, tables, figures, schematic representations) provided in printable form.

6. Legends to tables and figures.

Original contributions should include the following parts: Introduction - Patients and methods - Results - Discussion - Conclusions. It is not recommended to abbreviate terms (especially so in titles of manuscripts). Should a term often repeat in the text, and the author(s) think it appropriate to abbreviate it, they should indicate the abbreviation in brackets after it was first used.

References should conform to the standard accepted by prestigious medical journals. The full form of citations should be used (last names and initials of the first names of all authors, full title of the cited work in the original language, year of publication, volume, pages; in monographs, the place of publication, publisher, year of publication, and number of pages). The initials are to be written without full stops, and no spaces are to be made between the signs separating the year, volume and pages.

\section{EXAMPLES OF REFERENCING TO}

\section{An article published in a journal:}

Schwartz PJ, Priori SG, Vanoli E, Zaza A, Zuanetti G. Efficacy of diltiazem in two experimental feline models of sudden cardiac death. J Am Coll Cardiol 1986;8:661-8.

(If there are more than six authors, the first three are to be listed followed by et al.).

\section{A monograph:}

Eisen HN. Immunology: an introduction to molecular and cellular principles of the immune response. 5th ed. New York: Harper and Row, 1974:406.

\section{A chapter of a monograph:}

Streeter DD Jr. Gross morphology and fiber geometry of the heart. In: Berne RM, Sperelakis N, eds. Handbook of Physiology. The Cardiovascular System. Washington, D. C.: American Physiology Society, 1979:61-112.

The Editorial Office invites all authors to submit short communications. Short communications should not be longer than 3 pages, the Editorial Office will publish them within the shortest time possible, and they will not be subject to the review process. Still, these short communications should include an abstract and key words. These short communications will express the author's view, which need not be necessarily identical with that of the Editorial Board members and the Editorial Office.

The Editorial Office asks all reviewers of manuscripts submitted for publication in Cor et Vasa to write their own commentaries to manuscripts they deem interesting and would like to comment on. Such commentaries should be sent together with the reviewer's assessment so the manuscript could appear together with the commentary. 